Requests for reprints, lists of titles available, etc., should be addressed to The Social Research Center, The American University in Cairo, $x_{3} 3$ Sh. Kasr El Aini, Cairo, Egypt.

\title{
Dr. D. J. Stenning: Papers on Banyankole
}

The papers of the late Dr. D. J. Stenning, mainly on Banyankole, have been deposited in the Cambridge University Library by Mrs. Sheila Stenning.

Dr. M. J. Field (1899-1972)

DR. M. J. FIrLD, who died on 12 June 1972, was a pioneer in ethnopsychiatry. Graduating in chemistry in 1923, she went to Ghana in 1929 to teach at the Prince of Wales College in Achimota, where her interest in anthropology led to a Ph.D. degree in 1936. She became especially concerned with studies of traditional native healers and shrine priests. This led to an emphasis on the psychology, sociology, and psychopathology involved in native treatment methods, particularly at the healing shrines, so closely linked with local religiousmagical beliefs. In 1937 she was appointed as a government anthropologist in the Gold Coast and made a close study of the Ga. Her researches on their treatment of illness led her to take up the study of medicine herself and in I95I she qualified with an M.B. from Edinburgh. She then worked for several years in mental hospitals, which gave her a most unusual and solid grounding for further work in Ghana. She returned to Africa in 1956 on a Medical Research Council grant as a senior research fellow at the Ghana Academy of Sciences. Dr. Field's many published works include Religion and Medicine of the Ga People, Social Organization of the Ga People, and, perhaps best known, Search for Security, a study of the suppliants at the shrines of rural Ghana and of the mental illness and possession states she observed among them. (We are indebted to Professor Edward L. Margetts for information on Dr. Field's career.)

\section{Report on the International Conference on Manding Studies}

THE first international Conference on Manding Studies was held from 30 June to 3 July by the Centre for African Studies at the School of Oriental and African Studies, in association with the French Société des Africanistes. On the preceding day, 29 June, a joint meeting was held at the School between members of the Société and members of the African Studies Association of the United Kingdom.

The Conference formed part of a continuing programme of education and research sponsored by the School of Oriental and African Studies, devoted to the study of the Manding civilization of West Africa. The term 'Manding' has been used to cover a numbee of West African peoples (including the Mandinka/Maninka, Bambara, Dyula, Dyakhanka, Khassonke, Kuranko, Kono, and Vai) who speak related forms of the same language and share similar cultures. The Manding language, in a variety of dialects, is spoken as a major language in nine West African states-The Gambia, Guinea, the Ivory Coast, Liberia, Mali, Portuguese Guinea, Senegal, Sierra Leone, and Upper Volta-and also by small minorities in Ghana, Mauritania, and elsewhere. It is thus one of the major languages of Africa, spoken across an area r,200 miles wide. It was formerly associated with the medieval empire of Mali, governed from the Manding heartland on the Upper Niger, which flourished between the thirteenth and sixteenth centuries. At the height of its power, the Mali empire dominated a major part of West Africa, and its influence continues to pervade the culture and traditions of numerous Manding and non-Manding speaking peoples.

Despite the importance of the Manding, the co-ordinated study of their civilization had previously been hampered by modern political frontiers in West Africa, by ethnic divisions among the peoples involved, and by inadequate contact among scholars in different 